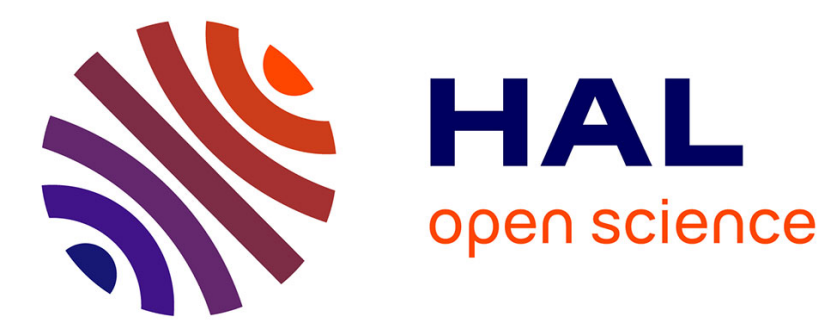

\title{
WEST regular in-vessel inspections with the Articulated Inspection Arm robot
}

\author{
V. Bruno, L. Allegretti, A. Barbuti, S. Bremond, Y. Cheng, C. Dechelle, N. \\ Dufour, H. Feng, L. Gargiulo, D. Mouyon, et al.
}

\section{- To cite this version:}

V. Bruno, L. Allegretti, A. Barbuti, S. Bremond, Y. Cheng, et al.. WEST regular in-vessel inspections with the Articulated Inspection Arm robot. Fusion Engineering and Design, 2018, 10.1016/j.fusengdes.2018.11.050 . cea-02092578

\section{HAL Id: cea-02092578 https://hal-cea.archives-ouvertes.fr/cea-02092578}

Submitted on 8 Apr 2019

HAL is a multi-disciplinary open access archive for the deposit and dissemination of scientific research documents, whether they are published or not. The documents may come from teaching and research institutions in France or abroad, or from public or private research centers.
L'archive ouverte pluridisciplinaire $\mathbf{H A L}$, est destinée au dépôt et à la diffusion de documents scientifiques de niveau recherche, publiés ou non, émanant des établissements d'enseignement et de recherche français ou étrangers, des laboratoires publics ou privés. 
Topic: Vessel/In vessel Engineering and Remote Handling

\title{
WEST regular in-vessel inspections with the Articulated Inspection Arm robot
}

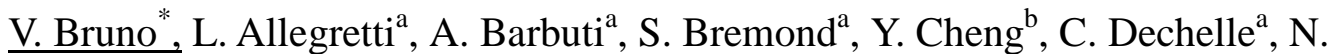

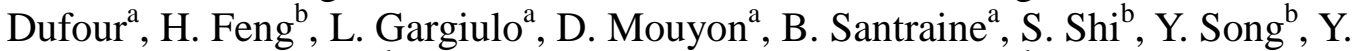 \\ Sun $^{\mathrm{b}}$, E. Villedieu ${ }^{\mathrm{a}}$, B. Vincent ${ }^{\mathrm{a}}$, L. Zheng $^{\mathrm{b}}$ \\ ${ }^{a}$ CEA, IRFM, F-13108 Saint-Paul-Lez-Durance, France \\ ${ }^{b}$ CAS, IPP, Hefei, Anhui, China
}

*Corresponding author: vincent.bruno@cea.fr

Currently on fusion devices, diagnostics are mainly aiming at plasma analysis and control. However, operational and programmatic needs have appeared for regular in-vessel components monitoring during plasma campaign. Light robotics systems could meet this requirement and may be a way as well to replace human interventions to fix damaged in vessel components. To minimize the impact on machine operation, the robotic system has to be mini-invasive and compatible with operating conditions (vacuum, temperature, radiation...).

To fulfill this goal, CEA has developed a multipurpose carrier able to be operated inside WEST vessel between plasma pulses. A prototype of this robot, called Articulated Inspection Arm (AIA), was tested in 2008 in Tore Supra vacuum vessel. A major upgrade was performed in 2014-2015 with the aim of converting this prototype into a reliable tool in support to WEST operation. During the WEST components manufacturing and installation (2014-2016), the robot was integrated and tested in the EAST Tokamak.

Since 2017, the AIA has been regularly used during the WEST plasma campaigns. Movies provided by the embedded camera allow to assess the evolution of Plasma Facing Components surface state and the effects of plasma loads, runaways and disruptions.

The robot operation was also very helpful to assess the needs for maintenance, to assist mechanical assembly without man entry and to perform diagnostics calibration under relevant conditions.

The paper will detail lessons learned from the robot integration and use on the WEST Tokamak. Future developments for innovative embedded diagnostics will also be presented.

Keywords: WEST, assembly, operation, robotics 